$\sqrt{\beta}$

J. bio-sci. 15: 169-171, 2007

ISSN 1023-8654

http://www.banglajol.info/index.php/JBS/index

-Short Communication

\title{
STATUS OF AQUARIUM FISHERIES OF RAJSHAHI CITY
}

\author{
A B M Mohsin ${ }^{1}$, Md Emdadul Haque ${ }^{2}$ and Md Nazrul Islam³ \\ 1,2 Department of Fisheries, University of Rajshahi, Rajshahi-6205, Bangladesh \\ 3 Department of Zoology, University of Rajshahi, Rajshahi-6205, Bangladesh
}

An aquarium is an enclosed body of water containing a mixture of selected and unselected captive living aquatic organism. It is essentially unstable and to obtain stability must be carefully designed and managed (Suxena 2003). Recently aquarium technology means that the technical problems of keening aquatic animals have in principle been solved. It includes about water preparation and the constant monitoring of water quality i.e. pH, hardness, dissolve oxygen, temperature etc. and for this heater, pumps and filter is used. For first time colorful fishes are imported in our country in 1992 and the business was confined in some limited shops of Katabaon area of Dhaka city. But now this business is very common in all over the country (Akhter 1995). It is not only enhancing the beauty of a house but also it is a source of recreation. Japanese can realize the presage of earthquake or can predict about natural disaster by watching the sudden movement of the aquarium fishes (Shafi 1998). Similarly to get rid of mental stress, watching fish is reported well and this also helps to decrease the high blood pressure (Hervert 1999). In Rajshahi city aquarium business started at the last decade and it is spreading rapidly. So development of aquarium fisheries is highly significant here.

This investigation was conducted over a period of 12 months from September 2004 to August 2005. A details information about aquarium fisheries were collected concerning shape and size, structural materials, functional equipment, decorative equipment and their sources, types of aquarist and their personal information, set up process, water quality monitoring and management, sto cking and selection of species, feeding, breeding, disease and water changing and tank cleaning etc. All the mentioned data were collected by using survey method in randomly selected houses and all the shops of aquarium in Rajshahi city. During the investigation the principle working tools were face to face interview, Diagramming and Photographing. Collected data were analyzed manually and with the help of spreadsheet program.

The transparent glass made aquarium represents various types of attractive shapes and size. Physically the basic components of an aquarium is glass, silicon, wood, white gravel, marble stone, black gravel which costs in an average of $45 \pm 14 \mathrm{BDT} / \mathrm{feet}, 310 \pm 14 \mathrm{BDT} / \mathrm{pack}, 525 \mathrm{BDT} / \mathrm{box}, 6 \pm 0.7 \mathrm{BDT} / \mathrm{kg}, 31 \pm 5 \mathrm{BDT} / \mathrm{kg}$ and $4 \pm 1 \mathrm{BDT} / \mathrm{kg}$ respectively. Some ornamental equipment is also used to decorate the aquarium. The average costs of these decorative equipments are as follows, plastic plants ( $37 \pm 24 \mathrm{BDT} /$ piece), plastic wheel $(45 \pm 3$ $\mathrm{BDT} /$ piece), plastic fish ( $27 \pm 3 \mathrm{BDT} /$ piece), wall paper ( $47 \pm 3 \mathrm{BDT} /$ feet) etc. Some functional equipment like aerator, hearer and light are also required which costs as 120-550, 70-550 and 20-250 BDT/piece

\footnotetext{
? To whom all correspondence should be addressed.
} 
accordingly. Chemical like table salt and methyl blue is used to clean the tank while set up and after construction during rearing as antiseptic and germ killer. Retail price of table salt is $10 \mathrm{BDT} / \mathrm{kg}$ and methyl blue is $15 \mathrm{BDT} /$ pack. Live ornamental fishes and some aquatic plant are the main biological element of an Aquarium. Twelve ornamental species are available in Rajshahi city, which are given at the following Table1.

Table 1. A list of available aquarium fishes of Rajshahi City with prices.

\begin{tabular}{|c|c|c|c|}
\hline SL & Local name & Scientific name & Price (BDT/pair) \\
\hline 1 & Gold fish & Carassius auratus & $60-300$ \\
\hline 2 & Clown loss & Botio macrocantha & $60-300$ \\
\hline 3 & Angel fish & Pterophyllum scalare & $40-60$ \\
\hline 4 & Asker fish & Asrtonotus ocetlatus & $60-100$ \\
\hline 5 & Kissing gorami & Heloistoma temmineki & $70-150$ \\
\hline 6 & Guppy & Poecilia reticulata & $20-40$ \\
\hline 7 & Pearl gorami & Tricogaster leeri & $60-120$ \\
\hline 8 & Fighter fish & Betta splendens & $60-80$ \\
\hline 9 & Black molly & Poecilia hybrid & $30-60$ \\
\hline 10 & Tiger shark & & $30-50$ \\
\hline 11 & Sucker fish & Plecostomus punctatus & $60-80$ \\
\hline 12 & Glass catfish & Krypoptrerus bicirrhis & $60-120$ \\
\hline
\end{tabular}

Aquarium management is a hobby of all ages. In Rajshahi $57 \%$ aquarist are student and rest $43 \%$ include mostly teacher, lawyer, restaurant and clinic boys etc. Aquarium set up is depends upon one's choice and financial ability. First step is to select an aquarium jar and most of the aquarist of Rajshahi city choices rectangular (69\%) and ball (29\%) jar. Very few likes pentagonal or hexagonal or octagonal jar (2\%). Then the jars are decorated by various kinds of decorating materials. Major species selection criteria are the body color and adaptive power. Gold fish found in almost $82 \%$, Tiger shark and Suckerfish are found in $42 \%$ and $24 \%$ aquarium orderly. In case of stocking about $25 \%$ single, 19\% double, 19\% triple, $25 \%$ tetra and $12 \%$ hexa species combination was observed. Two native colorful species "Kholisha" and a cultural species "Common carp" were also found in some aquarium. The ornamental fishes are reared totally depended upon marketed brand feed. This feeds are granular in size and given daily to the fishes. Feeding amount is about $11.5 \pm 5$ for Gold fish, $4.5 \pm 2$ for Shark group, $5 \pm 1.4$ for Sword tail, $3.5 \pm 7$ for color comet, $2.5 \pm 7$ for Moly group, Guppy, Kholisha, Sucker and Angel fish and for large native species $55 \pm 7$ granules per day was observed. No live feed application was found. Most of the aquarist use tap and/or tube-well water for their 
aquarium and have no proper knowledge about the water quality maintenance. They just apply some common steps (water changing, use of aerator, heater, filter, salt and blue etc.) suggested by the aquarium shop keeper. When the water body becomes turbid $68 \%$ aquarist applies partial water changing method and $32 \%$ aquarist applies fully water changing methods. The duration of this water changing is about $47 \%$ once in a month, $18 \%$ once in three months and $11 \%$ once in six months. Some chemicals are found to use purifying tank water. Use of aerator, heater, light, and filter is found in about $47 \%, 21 \%, 64 \%$ and $46 \%$ aquarium. Disease is not so prominent in Rajshahi city. Some times few fishes are dies because of mass density in the tank or water quality degradation.

In Rajshahi, modern technology of aquarium structure and management are not introduced yet. Acrylic jar is more clear and attractive (Gordon and Michele 2003) but it is not available here. About 700 ornamental species are found all over the world for aquarium rearing (Rahman 2002) but limited species are found in Rajshahi. For better survival and management of aquarium fish specific amount of area is required in aquarium tank (Haque 2005) but people gather a lot of fishes in a limited water area which cause fish death or less growth or lazy movement. Tap water may contain chlorine which is harmful for fish gill (Bridge 2005) but it is found to use in most aquarium. Live feed is proves good for ornamental fish health and body color (Vevers 1979) but it has not been applied totally. Ornamental fish keeping is not only a popular hobby but also a growing business for aquarium traders. Most of the people like this hobby but some times they do not take any attempt to establish an aquarium in their home due to lack of proper knowledge and essential equipment to operate an aquarium. For this reason sometimes fishes die and people are giving up this hobby with great remorse. By solving these problems it could be possible to establish this sector as a field of learning, earning and recreation.

\section{References}

Akhter S M (1995) Aquarium guide. Echo aqua fisheries project. Dhaka, 1st edition. 71 pp

Bridge P (2005) Basic guide of successful fresh water aquarium. www.aquarticles.com

Gordon A and Michele S (2003) Aquarium tank, uww.aquarticles.com

Hervert (1999) A guide to freshwater fishes. Revised edition, Hamlyn.

Rahman Y (2002) Rearing of ornamental fishes in aquarium. Matsaw pakkha sangkalan, Rajshahi division, 60-61 pp.

Shafi M (1998) Native ornamental punti fish rearing in aquarium. Matsaw pakkha sangkalan, DoF. Dhaka, 31 pp

Suxena A (2003) Aquarium management. Daya Publishing House. New Delhi-110035. 230 pp

Vevers G D (1979) Tropical Aquarium Fishes. Salmandar Books Ltd. 52, Belford Road, London. 